\title{
Aus dem schwäbischen Pfarrhaus nach Amerika: \\ Reiseschilderungen (1860): \\ Louise Weil's America as Experience and Fiction
}

\author{
Judith E. Martin
}

$\mathrm{I}$

$\mathrm{n}$ her autobiographical travelogue, Aus dem schwäbischen Pfarrhaus nach Amerika: Reiseschilderungen ("From the Swabian Parsonage to America:

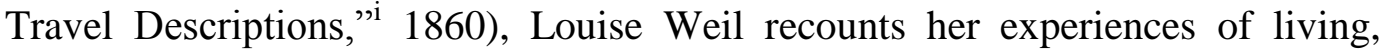
teaching, and traveling in the United States for nearly five years, beginning in 1854. Responding to the flood of German immigration to America in 1852-54, Weil's declared aim is to rectify idyllic images of America put forth to would-be immigrants by presenting a realistic assessment of American life and institutions. ${ }^{i i}$ Far from idealizing the United States, Weil condemns slavery and capitalist greed, two phenomena that exemplify America's failure to live up to its founding ideals of equality and freedom. Although such criticisms were commonplace in European writings about America, Weil's in-depth account of her unique experiences with American race relations and religious utopianism distinguishes her writing from the German literary clichés of racism and commercialism. iii Rather than merely observing as a visitor, Weil participated as a professional educator in two communities that permitted her intensive encounters with distinctive features of nineteenth-century American life: specifically the abolitionist movement in Cincinnati, and the intentional community "Economy" in Pennsylvania. ${ }^{\text {iv }}$ Established in the early nineteenth century by the German immigrant Johann Georg Rapp, Economy was a utopian religious community famous for its economic prosperity and for the celibacy of its members. The group, known either as Rappites or Harmonites (for its two earlier settlements named Harmony), lasted for nearly one hundred years, and drew international visitors, including the Duke of Saxe-Weimar and the poet Niklaus Lenau. ${ }^{\mathrm{v}}$ Weil's 
extended account of life there at mid-century lends her travelogue lasting relevance.

Several years after publishing her travelogue, Weil transformed her American experiences into fiction in a collection of stories (titled Amerikanische Lebensbilder oder Erlebnisse deutscher Auswanderer in Amerika, Pictures of American Life, or Experiences of German Emigrants in America, 1865) that, taken on their own, appear conventional, and in some cases even trivial. Yet in light of her travelogue, we see that the stories illustrate, in popular form, Weil's insights into the lives of immigrants in America. Two of the stories in the Lebensbilder collection hold particular dramatic and thematic interest, though they also blend melodrama and didacticism. The first, "Der deutsche Sklavenhalter" ("The German Slaveholder"), recounts the moral decline of a German theology student who becomes a slave-owner, while the other, "Marias einzige Liebe" ("Maria's Only Love”), presents a melodrama of lost love set in a religious community that forbids marriage. ${ }^{\mathrm{vi}}$ Based on Weil's first-hand encounters with individuals of mixed racial heritage in Cincinnati and on her life at Economy, these two stories reflect her concerns with American culture, and hence serve as a study of Weil's perspective on gender, racism, and national identity for German immigrants in America.

Tracing transitions and continuities between Weil's nuanced analyses in her travelogue, Reiseschilderungen, and their sentimentalized fictional versions in the Lebensbilder, brings into focus the shaping force of genre and audience on her texts. Despite their differences, both her fiction and non-fiction works grapple with crucial historical and cultural issues of her day, reflecting on contemporary controversies over gender, race, religion, and national identity. When Weil's writing is situated within this historical context, it sheds light on her complex perspectives regarding women's social role; slavery; and German identity vis-àvis American race relations and religious practice. By addressing limiting conceptions of female authorship, Weil thematizes gender in the travelogue, and also emphasizes women's experiences in her short stories. Weil's accounts of the 
oppression of slaves and freed blacks reveal her understanding of the intersections between gender, race, and class relations. Furthermore, in her writings Weil constructs both an American and a German national identity, not only by foregrounding American shortcomings in racial and religious matters, but also by implying that Germans in America should adhere to their moderate humanitarian cultural and religious values rather than succumbing either to American materialism or to religious legalism. While the scant scholarship on Weil has focused exclusively on her travelogue, Reiseschilderungen, this essay will examine the interlocking nature of gender, race, and nation in both the travelogue and the fictional Lebensbilder. Reading the two Lebensbilder stories, "Der deutsche Sklavenhalter" and "Maria's einzige Liebe," in relation to the travelogue will elucidate how Weil's seemingly simple use of the romance genre is made more complicated by her social concerns.

Though sentimental fiction writing may have required little justification for a woman, Weil shared with other nineteenth-century women travelers the need to legitimate her publication of non-fiction, which was considered the domain of male discourse (Foster 18-19). In order to establish her authorial legitimacy as a woman, Weil stresses both her religious background as the daughter of a minister and her role as a professional educator. Despite occasional modestly feminine disavowals, Weil assumes a masculine posture of authority in the foreword to Reiseschilderungen by refuting earlier accounts and asserting her unique access to information through what Monica Anderson would call her "insider position". vii Contending that "die besondern Umstände" ("the particular circumstances") of her visit provide her with "manches Neue und Wissenswerthe" ("quite a few new and interesting facts") to communicate, Weil authenticates this claim with her knowledge and experience: "Ich habe einigen Einblick in die amerikanischen Verhältnisse gewonnen, und da ich mit der Sprache des Landes von Anfang an bekannt war, so ist mir Manches klar geworden, was den meisten Andern verborgen bleibt" (Reiseschilderungen, Vorrede, 7; "I have gained a certain insight into American circumstances, and since I was familiar with the language 
of the country from the beginning, quite a few things became clear to me that remain hidden from most others"). The apologetic disclaimers she sprinkles throughout the text seem strategically aimed to counterbalance the bold presumption by a woman that she comprehends America better than other visitors.

A similar didactic gesture introduces Weil's story collection,

Lebensbilder. In the foreword to the Lebensbilder, Weil declares that her intention is "die Stellung der Deutschen in Amerika im Allgemeinen möglichst getreu zu schildern" (Lebensbilder, Vorwort 7-8; "to relate the status of Germans in America as faithfully as possible"). She hopes to provide "einen richtigeren Begriff über das dortige Leben" (“a more accurate conception of life there") than that presented in reports of paid agents or "eigennütziger Bekannten und Verwandten" (Lebensbilder, Vorwort 7-8; "self-serving acquaintances and relatives") who live there. Her target audience is comprised of people who regard the New World with “sehnsüchtigen Blicken” (Lebensbilder, Vorwort 7-8; "yearning looks") due to the newly awakened desire for emigration. ${ }^{\text {viii }}$ Most of Weil's Lebensbilder stories, in predictable sentimental mode, rely on stereotypical figures and didactic devices, such as "Die Waise" ("The Orphan”), about a destitute but virtuous German immigrant girl whom a wealthy New Yorker rescues and marries. Another story, "Der Student als Farmer" ("The Student as Farmer"), reinforces Weil's contention in the travelogue that educated Germans tend to idealize farm life in America, and all too often fall prey to unscrupulous Americans who sell them poor land and offer bad advice. Her fictional farmer lacks practical knowledge and experience, thus dramatizing Weil's hope:

manchen jungen Mann vor einer unbesonnenen Reise in die neue Welt abzuhalten, durch die er leicht in das größte Unglück gestürzt werden oder gar seinen Untergang finden könnte. Selbst Männer mit bedeutendem Vermögen, die sich blenden lassen durch den Reiz einer amerikanischen Farm, sind schon in die bitterste Armut und in das größte Elend geraten, wenn sie das was sie etwa aus Büchern von der Landwirtschaft erlernt 
hätten in der neuen Welt ins praktische Leben übertragen wollten.

(Reiseschilderungen 107).

to deter some young men from an imprudent voyage to the New World, through which they could be easily ruined or even perish. Even men of significant fortune, who let themselves be bedazzled by the allure of an American farm, have gotten themselves into the most abject poverty and the greatest misery, by wanting to transfer what they had learned about agriculture in books into practical life in the New World.

But the would-be farmer in "Der Student als Farmer" does not fail on his own; rather, in an exaggerated ethnic stereotype, a vicious Irish woman named Molly conspires with her lover to marry the protagonist in order to ruin him and appropriate his land. Even though several of Weil's stories rely on such clichéd figures and implausible coincidences, Weil introduces them in the foreword as based mostly on facts. ${ }^{\text {ix }}$

In both the Lebensbilder and Reiseschilderungen, Weil draws on a metanarrative of gender based on women's purported affinity for domesticity and religious sentiment, yet she simultaneously negotiates between this conservative doctrine of the sacred influence of women on the one hand, and public activism on the other. ${ }^{\mathrm{x}}$ Weil's writings impart sympathy for women and children of all races, which constitutes a potent form of female emotional - and hence also social - authority. Given the dearth of sources by immigrant women, the emphasis on women's social and sexual experiences in both Weil's fiction and non-fiction is particularly valuable. ${ }^{\mathrm{xi}}$ Although her exploration of gender and race through the filters of religion and education resembles American abolitionist women's writings, Weil is unique in the combination of her female perspective on German immigrants' circumstances with her unequivocal abolitionist stance. As Linda Kraus Worley demonstrates, both Weil's extended stay as an intentional immigrant and the negative tone of her commentary set her apart from other German women visitors (42). 
In Weil's travelogue, Reiseschilderungen, reflections on race and religion overlap with a strategic deployment of gender in her critique of American society. She underscores contradictions between American egalitarianism and racial prejudice by playing gender equality against racial inequality. When Weil makes a disapproving comment about racial prejudice, a young Southern woman retorts: "Miss W., in dieser Frage haben Sie keine Stimme! Wie ich erfahren habe, sind Sie eine Deutsche; die Deutschen aber sind von Haus aus Sklaven, und zwar sind die Frauen die Sklavinnen ihrer Männer, und ihre Männer die Sklaven ihrer Fürsten!" (Reiseschilderungen 172; "in this matter you have no voice! As I have learned, you are a German; and the Germans are slaves by nature, namely women are the slaves of their husbands, and their husbands the slaves of their rulers!"). Weil is tempted to respond, "dass in Amerika die Männer die Sklaven ihrer Frauen seien" (172; "that in America the men are the slaves of their wives"), but she holds her tongue to avoid alienating the others present. Her jab at American inconsistencies hinges on the greater independence and freedom of movement for women in America than in Germany, an aspect that German male authors writing about America often deplored. ${ }^{\text {xii }}$ Although Weil reiterates the German stereotype of the American woman who enslaves her husband, she transforms it from a belittling caricature of egalitarian American gender relations into a condemnation of American racism and a simultaneous defense of German identity. ${ }^{\text {xii }}$

Weil comments at some length on race relations in her travelogue, relating that while working as a teacher in Cincinnati, she had ample opportunity to gain an impression of reality in the slave states (Reiseschilderungen 165) ${ }^{\mathrm{xiv}} \mathrm{Her}$ description of "haarsträubende Szenen" (165; "hair-raising scenes") she witnessed of escaped slaves being recaptured and bound conveys the effects of the Fugitive Slave Act. She openly defies American law in declaring that, "[j]eder rechtschaffene, menschlich und christlich denkende Amerikaner hält es für eine unabweisbare Pflicht einem entlaufenen Sklaven durch- und zu seiner Freiheit zu verhelfen, obgleich die härtesten Strafen darauf gesetzt sind" (165-66; "every 
upright, humane and christian-thinking American considers it an undeniable duty to help an escaped slave to freedom, although it carries the harshest penalties").

Weil's situation in an abolitionist milieu in Cincinnati afforded her painful insights into the deep contempt in America for people of African descent, without regard for their education or wealth or even for those whose skin color betrayed no trace of their background (Reiseschilderungen 168). Weil lodged at the home of an elderly Quaker couple, Onkel Levi and Tante Katy, who welcomed people of mixed racial backgrounds at their table. Although Weil and the other female teachers living there had no objection to eating with a light-skinned young pharmacist of interracial descent, a visiting Presbyterian minister from the South left the table in horror when he learned of the man's identity (169). This pharmacist's beautiful and accomplished sister had been rejected by a white Southern suitor when she divulged that her mother was mulatto-a revelation she made in response to his remark that he considered blacks and their descendents "nur als Tiere, höchstens als Halbmenschen" (170; "merely to be animals, or at most as semi-human"). In an incident that caused a public controversy in Cincinnati, a teacher at Weil's school expelled a boy from her class when she learned that his parents were of distant African ancestry. Weil relates these episodes to undergird her premise that slaveholding is inconsistent with Christianity. She nevertheless qualifies this premise by giving as her "bescheidene Privatmeinung" (171-72; "humble private opinion") the assertion that slavery makes a mockery of missionary efforts among the "heathen," as long as those who consider themselves to be Christians keep slaves. Such apologetic disclaimers which apparently devalue her opinion-typical of nineteenth-century German women who venture into public affairs - serve in fact to legitimize Weil's forceful expression of her racial and religious views. ${ }^{\mathrm{xv}}$

Another of Weil's Cincinnati anecdotes conveys her special moral indignation over the sexual exploitation of female slaves. Onkel Levi and Tante Katy made a practice of hiring freed slaves as their servants, and among these was a fair-skinned sixteen-year-old who was already a mother. When she gave birth, 
her owner and the father of her child, a Louisiana planter, had set her free and sent her north to Cincinnati, where, with no means of supporting herself, she and the child were near starvation when Onkel Levi found them (Reiseschilderungen 166). After recounting such instances of the injustices of slavery, Weil not only labels herself an abolitionist, but even reveals that she met people who helped slaves escape to Canada on the Underground Railroad. She also notes that she attended several meetings on emancipation held by a women's group that made charitable donations to escaped slaves $(168,172-73)$. Moreover, Weil justifies women's presentation of "gelehrte Vorträge" ("erudite presentations") about abolition at these meetings with the argument that slavery "dringt . . . in alle Verhältnisse und bis in das innerste Heiligthum der Familien" (172; "thrusts itself into all relations, even into the most sacred one of the family"). This assertion by the usually cautious Weil endorses the concatenation of abolitionism and feminism in nineteenth-century America. ${ }^{\text {xvi }}$

Several themes from Weil's non-fiction writings on race relations reappear in her narrative "Der deutsche Sklavenhalter" ("The German Slaveholder"), the first and longest story in the Lebensbilder collection, including her admiration for the Quakers who are activist abolitionists, her dismay at the sexual plight of women slaves, and her grasp of the public controversy in the press over racial incidents. In "Der deutsche Sklavenhalter," the apparently white Nelly discovers her identity as a slave, flees the threat of sexual concubinage by escaping to Cincinnati, and eventually marries a white northerner. The narrative connects the story of the German immigrant and plantation owner, known only as Mister Haller, with that of Nelly, his daughter by a slave. After her mother's death, Haller had sent Nelly north to be raised in a white family in New England. Now an adult, she is due to return to her father, but because Haller forfeited ownership of Nelly at the gambling table, he must deliver her to a lascivious slaveholder. The dramatic action of the story centers on Nelly's escape after she discovers her identity and learns the story of her mother Lucy, Haller's consensual lover, who died after a harsh whipping by his jealous wife. Weil's focus on women in slave 
society draws on American antislavery literature, but by framing the sexual exploitation plot with Haller's moral degeneration from German piety to American greed, she dramatizes a German intellectual's corruption under the influence of colonial race relations. ${ }^{\text {xvii }}$

The opening scene of "Der deutsche Sklavenhalter" reflects Weil's concerns as an educator, as Haller observes his daycare for slave children from his veranda. Irritated by their noisy games, Haller sends a mulatto slave to silence them with a whip. This harshness deviates from his usual mild treatment-Haller intentionally refrains from overworking or abusing his slaves in order to obtain healthy children to sell. Weil's depiction of the slave daycare as a colonial perversion of educational institutions corresponds to Ann Laura Stoler's tracing of the significance of colonial nurseries and schools in "disciplining aspirations and policing the boundaries of race" (47). Haller's slave nursery represents a travesty, not only of family relations but also of educational ideals, such as those of the Kindergarten movement, which began in Germany in the 1820s (Stoler 45). Weil reiterates the theme of education in Nelly's careful upbringing by her foster parents, who are as concerned "ihr einen christlich frommen Sinn einzupflanzen," (Lebensbilder 17; "to instill in her a sense of Christian piety"), as they are with imparting knowledge.

Haller represents failed fatherhood as well, since his bad mood on this particular day results from self-reproaches over gambling away Nelly's freedom. Through Haller's internal conflict between his right of ownership and his promise to her mother that he would provide Nelly with a good education and her freedom, Weil juxtaposes the worst effects of racial ideology with the German religious values Haller has abandoned. He acknowledges the depths of his debasement by the plantation system when he exclaims, "warum bin ich aus einer so glücklichen Heimath geschieden, wo man sich von solchen Verbrechen nichts träumen läßt; warum bin ich in dieses unselige Land gekommen, das keinen andern Gott kennt, als den des Geldes, wo jede edlere Regung der Habgier unterworfen wird!" (Lebensbilder 8-9; "why did I depart from such a happy 
homeland, where one does not even dream of such crimes; why did I come to this ill-fated land that knows no other god but money, where every nobler impulse is subordinated to greed!"). As a theology student in Germany, penniless after his parents' death, Haller had accepted an invitation to join his plantation-owner uncle in Louisiana. After his initial shock over the treatment of slaves, Haller becomes inured to their subordination. His better impulses move him to buy Lucy out of pity, and they fall in love, but a few years later Haller deserts her for an advantageous marriage with a Creole woman, under whose influence he becomes obsessed with greed and gambling (15).

Seeing the seventeen-year-old Nelly reawakens Haller's conscience, which prompts him to plan her rescue. Unaware of his intentions, Nelly escapes with the help of a female slave, taking refuge with a Quaker couple whose home is a station on the Underground Railroad. Weil integrates her familiarity with the abolitionist press when the Quaker husband, Onkel Levi- the name is clearly a reference to Weil's landlord in Cincinnati-publishes a newspaper article recounting Nelly's tale. The article creates a sensation in wide circles, and the abolitionist papers use it to their advantage. The public circulation of Onkel Levi's article reflects the power of the press in the antebellum period for both the abolitionist and the proslavery causes, while simultaneously illustrating the potency of literary dramatizations of abolitionist slave stories, which were frequently reprinted. Onkel Levi's newspaper article recalls — and symbolically responds to - the previously-mentioned prejudiced minister in Cincinnati, who had retaliated for the "racial affront" he suffered in the Quaker home by publishing a racist article describing the incident. ${ }^{\text {xviii }}$

This evidence of Weil's acquaintance with abolitionist discourse coexists in the story with melodramatic devices. Nelly's ordeal eventually reforms Haller, and in a conciliatory ending he frees his slaves before his death, while Nelly marries her northern foster brother. At the same time, this conventional resolution is counterbalanced by Weil's less sentimental focus on slave women's double burden of racial and sexual oppression. 
Weil's contact with an antislavery social milieu in America predated her stay in Cincinnati, stemming from the time when she lived in Pennsylvania at Economy, a settlement founded by the German Pietist leader Georg Rapp. ${ }^{\text {xix }}$ Inspiration for the remarkable story in the Lebensbilder, "Maria's einzige Liebe" ("Maria's Only Love”), which decries the coercion of women's sexuality, came from the fifteen months Weil spent at Economy. In a lengthy section of her travelogue that describes her several extended sojourns at the community, she praises the kindness of the members, their peaceful, industrious way of life, and their ready aid to the needy. In fact, she characterizes her stay at Economy as one of the high points of her American experience, and dedicates her travelogue to its members in a poem (Reiseschilderungen 97). ${ }^{\mathrm{xx}}$ However, she also condemns "das unnatürliche Zölibat" (89; "unnatural celibacy"), which is leading to their "unvermeidlichen Untergang" (90; "unavoidable decline"). She is saddened to see so many abandoned houses in the town (out of some 200, only 50-60 are still occupied), and regrets the demise of such a prosperous and idealistic group: "Wie Schade dass diese Gesellschaft sich nicht mehr ergänzt, sondern ihrer gänzlichen Auflösung durch Aussterben getrost und freudig entgegensieht!" (89; "what a shame that this society no longer replenishes itself, rather it confidently and joyfully looks forward to its complete dissolution through extinction"). The opportunity to live within this community was unusual, as visitors who did not share their beliefs were not normally allowed to stay in private homes. Weil's permission to participate without being a member was granted due to a family connection: her grandfather had handled the group's financial affairs, and the current leader, R.L. Baker, had long ago visited her grandparents in Germany, where he met Weil's mother, then a young girl (84-85). In her short story, "Maria's einzige Liebe," Weil inscribes these autobiographical aspects in the young Franziska, a visitor to the community, and in the history of the protagonist Maria, whose father had known Rapp in Germany before emigrating. 
In "Maria's einzige Liebe," Weil dramatizes the irreconcilability of religious celibacy with the human need for love, affection, and connection. Maria, now older, explains to Franziska why she is crying one evening alone in the garden. In her youth she loved a local man named Paul, but refused to marry him because she had recently taken her vow of celibacy and pledged faithfulness to the community. Some months after she renounced him, he drowned while rescuing her from a raging river. Although Maria remains in the community, she never forgets Paul or stops loving him. Only after his death, however, can she permit herself to grieve for their lost love. In language that captures the emptiness of her sacrifice, she confesses, "ich darf ihn jetzt lieben, ohne dass es mir zur Sünde gereicht" (Lebensbilder 259; "I may love him now without it bringing sin upon me"). Although Weil strikes a milder tone than the sarcasm she turns on those who fail to recognize the contradiction between Christianity and slavery, this story articulates the author's rejection of celibacy as a misguided application of the doctrine of renunciation of earthly pleasures in the pursuit of religious salvation. By juxtaposing the spiritual views of the community with Maria's innate desire to give and receive love, Weil indirectly but insistently critiques religious legalism. Only Paul voices the outsider's standpoint on celibacy as deluded extremism when he redefines Maria's utterances about her own "Sünde und Schwachheiten" (Lebensbilder 247; "sin and weaknesses") as "Grillen" (247; "silly notions") and "Wahn" (250; “delusions"). Years later, Maria apparently endorses his position when she refuses to let her foster daughter make the same sacrifice, acknowledging, "ich hatte selbst zu viel gelitten, als dass ich dem lieblichen Mädchen die gleiche Last hatte auferlegen mögen" (260; "I had suffered too much myself to want to place the same burden on the sweet girl").

The historical "Father" Georg Rapp plays a central role in the figure of Vater Georg. Although he is portrayed as gentle and loving, he is nonetheless highly persuasive, and during Maria's religious instruction with him, she describes his "fast übernatürlicher" (Lebensbilder 232; "nearly supernatural") influence over her. This echoes Weil's travelogue, in which she underscores the 
extraordinary influence Rapp exerted over others, maintaining that the best proof of this lay in the unanimous resolution to ban marriage, which was taken four or five years after the founding of the first settlement, Harmony (Reiseschilderungen 83). The fictional Vater Georg, in trying to persuade Maria to remain loyal to her vow of celibacy, asks her, "Willst Du um irdischer Güter willen die ewige Seligkeit verscherzen?" (Lebensbilder 242; "Do you want to forfeit everlasting life for the sake of earthly goods?"), as he gently but firmly extricates her from Paul's embrace.

Weil's educational views find expression in her disapproval of the treatment of children in the fictionalized community of "Maria's einzige Liebe." She depicts childhood as devoid of normal play and instead dominated by school and physical labor in the fields and factory. Tellingly, Maria suffers a long illness from the overexertion of this lifestyle. ${ }^{\mathrm{xxi}}$ Not only were friendships with other children discouraged, but relationships between parents and children also lack affection. Maria's mother is serious and stern, embodying cold, joyless piety. Her father, although less reserved, extracts her promise at his deathbed, "den schmalen Pfad der Entsagung zu wählen" (Lebensbilder 231; "to choose the narrow path of renunciation"). Maria's story, then, is one of ever-increasing renunciation that begins in her early childhood, when her parents had been swept up in a pious religious movement in Germany. After this conversion, her mother threw all of Maria's toys into the fire and handed her a prayer book in their place. Her parents soon immigrated to America, joining the Rappite community Harmony in Indiana, where Maria spends her childhood, later moving with the group to Economy in Pennsylvania. Weil deplores the emotional isolation and later the sexual repression required of Maria, who grows to view herself as belonging exclusively to God. Although Maria's desire for love and marriage endorses notions of women's innate predilection for marriage and family, the narrator mobilizes this doctrine in order to validate female desire for emotional and erotic fulfillment in a mutual love relationship. ${ }^{\text {xxii }}$ A poignant scene of tender, lingering kisses before the lovers' final parting dramatizes Maria's sexual awakening 
simultaneously with its stifling by community expectations. The purely transcendent view of love as agape denies human, and specifically female sexuality.

Weil presents Maria's story as a unique tale of forbidden love that Maria is not at liberty to share with anyone in her community. Her decades-long emotional anguish belies the placid depiction of nature and the human hearts at Economy, with which Weil opens the narrative. Feeling death approaching, Maria tells the unauthorized version of her story secretly, and at night, when all the other community members are slumbering, passing it on to a young girl from outside who can transmit it to the world. The story thereby imagines a subversive transmission of female resistance to the excesses of religion from within a legalistic community. Furthermore, Weil's critique of the increasing self-denial among the Harmonites after their emigration to America suggests her more moderate conception of German identity in the United States, a country settled by religious dissidents, and therefore prone to fostering extremism. In rejecting the authoritarian elements of Harmonite society, Weil propounds a balance between Christian piety and social life. Her Quaker landlords, both fictional and in the travelogue, represent Weil's ideal role models for German Americans in combining deep religious feeling with social amelioration.

For all the conventionality of Weil's stories, she articulates her perspective as a woman in the stress she places on the particularity of women's psycho-social experiences in the uniquely American social groups she encountered, whether they be mixed-race individuals or Harmonites. Weil's commentary on American society, for example, in the two stories analyzed here, goes beyond reiterating one-dimensional stereotypes. Irmgard Scheitler asserts that German women discuss gender expectations and female authorship more explicitly in travel writing than in fiction, due to the former genre's claim of authenticity (245). This illuminates Weil's writing, whose fiction appears to endorse received stereotypical images of women, domesticity, and romance, while her travelogue confronts questions of women's social possibilities which are 
thrust on her through her encounter with another culture. Although she, like many other women authors of travel books, ostensibly accepted the ideal of domestic life for women, her approval, even partial and qualified, of American women's greater freedom, hints at an oblique challenge to German ideals of submissiveness (Scheitler 192; Anderson 26). The very act of writing on women's status-no matter how moderate the views - represents an appropriation of the authority to weigh in on this issue in a "distinctive and overtly feminine voice" (Foster 24). The ways in which Weil imagines and reinterprets women's experiences under slavery and within the Harmonite community reflect not only her social concerns as a woman, but also her interest in providing a female-authored version of America that could complement and correct the masculine perspective of German writing on the subject. Investigating these long-ignored writings by a woman provides an example of the unique contributions of women to fictional and factual writing on a variety of subjects that still command our interest, from historical immigrant experience and cross-cultural perceptions to race relations and utopian experiments in nineteenth-century America.

\section{Works Cited}

Anderson, Monica. Women and the Politics of Travel 1870-1914. Madison: Fairleigh Dickinson

University Press, 2006.

Arndt, Karl J. R. George Rapp's Successors and Material Heirs 18471916. Rutherford:

Fairleigh Dickinson University Press, 1971.

Berry, Brian J.L. America's Utopian Experiments: Communal Havens from Long-wave Crises.

Hanover, NH: University Press of New England, 1992. 
Foster, Shirley. Across New Worlds: Nineteenth-Century Women Travellers and their Writings.

New York: Harvester Wheatsheaf, 1990.

Hollyday, G.T. Anti-Americanism in the German Novel 1841-1862. Berne: Peter Lang, 1977.

Lockwood, George B. The New Harmony Movement. New York: D. Appleton, 1905. Reprint

New York: AMS Press, 1971.

Martin, Judith E. 'The 'Tragic Mulatto' in Three Nineteenth-Century German Antislavery

Texts." German Studies Review 32.2 (2009): 357-76.

Mikoletsky, Juliane. Die deutsche Amerika-Auswanderung des 19. Jahrhunderts in der

zeitgenössischen fiktionalen Literatur. Tübingen: Niemeyer, 1988.

Nordhoff, Charles. The Communistic Societies of the United States, From Personal Visit and Observation. 1875. Reprint With a New Introduction by Mark Holloway. New York: Dover, 1966.

Sammons, Jeffrey L. Ideology, Mimesis, Fantasy: Charles Sealsfield, Friedrich Gerstäcker, Karl

May, and Other German Novelists of America. Chapel Hill, N.C.: University of North

Carolina Press, 1998.

Scheitler, Irmgard. Gattung und Geschlecht: Reisebeschreibungen deutscher Frauen 1780-1850.

Tübingen: Max Niemeyer Verlag, 1999.

Stockwell, Foster. Encyclopedia of American Communes, 1663-1963. Jefferson, N.C.: McFarland, 1998.

Stoler, Ann Laura. "Tense and Tender Ties: The Politics of Comparison in North American 
History and (Post) Colonial Studies." Haunted by Empire:

Geographies of Intimacy in

North American History. Ed. Ann Laura Stoler. Durham: Duke University Press, 2006.

23-67.

Tompkins, Jane. Sensational Designs: The Cultural Work of American Fiction 1790-1860. New

York: Oxford University Press, 1985.

Walker, Mack. Germany and the Emigration 1816-1885. Cambridge: Harvard University Press,

1964.

Weil, Louise. Amerikanische Lebensbilder oder Erlebnisse deutscher Auswanderer in Amerika.

Stuttgart: Franckh, 1865.

---. Aus dem schwäbischen Pfarrhaus nach Amerika: Reiseschilderungen. Stuttgart: Franckh,

1860.

Woodward, C. Vann. The Old World's New World. New York: Oxford University Press, 1991.

Worley, Linda Kraus. "Through Others' Eyes: Narratives of German Women Travelling in

Nineteenth-Century America." Yearbook of German-American Studies 21(1986): 39-50.

\footnotetext{
${ }^{\mathrm{i}}$ All translations by the author.
} 
ii Although the emigration peak of 1854 declined in 1855 and remained low throughout the late fifties, Weil, who arrived in 1854, witnessed the conditions of poor immigrants who flooded seaports. She describes as well the hardships of poverty and unemployment that immigrants encountered in America due to an economic downturn there in 1854, and the intense anti-foreign feeling many encountered (Walker 171-75).

${ }^{\text {iii }}$ On clichés about American racism and commercialism in German fiction, see Sammons, 15257, 199. European commentators commonly denounce American materialism and deplore slavery as "the great American paradox" (Woodward 26, 19, 44). See also Hollyday 14 and, on women travel writers, Worley.

${ }^{\text {iv }}$ Mikoletsky provides scant biographical information on Weil (64-65). Weil's travelogue is the best source of information on her life. She left Germany as a seventeen-year-old to join her two older brothers, who had already emigrated.

${ }^{\mathrm{v}}$ For a brief history of the Harmony Society, see Stockwell, 193-97. For more detailed studies, see Arndt, Berry, and Nordhoff. The first Harmony was in Pennsylvania, where the society was located from 1804-1814. They then built an even more prosperous town, also named Harmony, on the Wabash River in Indiana, where they stayed for ten years, before selling it to the British social reformer Robert Owen, who renamed it New Harmony, and established a secular intentional community. The Harmonites moved back to Pennsylvania and built the town of Economy on the Ohio River, where they stayed until the society was formally dissolved in 1906. Both New Harmony, Indiana and Old Economy Village in Pennsylvania are preserved as National Historic Landmarks.

${ }^{\text {vi } W e i l ' s ~ e m p h a s i s ~ o n ~ t h e ~ p i v o t a l ~ r o l e ~ o f ~ r a c e ~ a n d ~ s l a v e r y ~ i n ~ b o t h ~ h e r ~ t r a v e l ~ w r i t i n g ~ a n d ~ f i c t i o n ~}$ reflects the widespread interest of the German public in this issue during the Civil War era. In Weil's collection of narratives, the story of the German slaveholder is placed in first position, denoting the dominance of this topic in German debate on America and emigration. She links the 
criticism of American commercialism, familiar in nineteenth-century German literature on America, with the evils of slavery that infect all aspects of American society: commerce, the law, and morality. Hollyday notes several other authors who relate slavery to their indictments of greed and violence in America (14).

vii Anderson 27. See also Foster 18 and Worley 41.

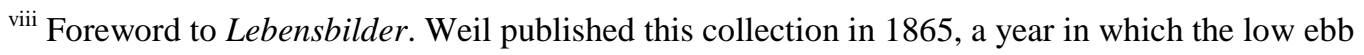
of emigration in the early sixties had begun to increase again (Walker 175). Adelbert von Baudissin, another author who spent much of the 1850s in America, states similar intentions to Weil's for his fictional works on life in America (Hollyday 77).

${ }^{\text {ix }}$ Weil may be taking her cue from American antislavery fiction, which was often presented as based on fact. Sammons points out that Friedrich Gerstäcker similarly justified his implausible plots by contending that real life can be unbelievable (199).

${ }^{\mathrm{x}}$ See Jane Tompkins's influential thesis that popular novels by nineteenth-century women inscribe a form of feminine authority derived from women's purported religious sensibility and domestic virtues.

${ }^{x i}$ See Mikoletsky 300, 307-08 on the paucity of sources by women. Other female travellers to America share Weil's emphasis on women and on the education and treatment of children. Such expressions of sympathy and identification with others tend to distinguish women's travel narratives from men's. On this tendency, see Foster 24, 74, 111, Scheitler 178-79, 194, and Worley 44-45. Worley examines the stances of three German and one Swedish traveller toward slavery and women's status and education, finding that Clara von Gerstner justifies slavery after visiting the South, 48.

${ }^{\text {xii }}$ Mikoletsky 305. Hollyday remarks that Baudissin and F.R. Eylert lambaste the American woman who enslaves her husband (155). 
xiii Interestingly, Anderson emphasizes women's “role as self-censor," which we can see in Weil's censoring of her retort in this scene. Also relevant is Anderson's claim that it was important for women travel writers to "gauge public opinion or feeling and then write to it," which they did in part by "including in their works recognizable literary and scopic elements from a variety of culturally acceptable texts" (28). In shifting the cliché of the too-independent American woman to the field of national identity, enunciated only in the version written for other Germans, Weil subtly renders her less traditional perspective on this masculinist stereotype more palatable to her audience.

${ }^{\text {xiv }}$ A later visit to her brothers in New Orleans reinforced her opinion of the inhumanity of slavery. There she saw slaves bent from whippings, and learned that many slaves were the offspring of their owners (251-55).

${ }^{\mathrm{xv}}$ Foster finds this type of self-effacing comment typical in nineteenth-century women's travel writing, 19-22.

${ }^{x v i}$ According to Worley, Weil's apparent approval of women's public speaking demonstrates her recognition that slavery provides American women a "mandate to act in the public sphere" (46).

${ }^{x v i i}$ For an examination of overlapping race and gender power dynamics in the stories of Nelly and her mother within the context of abolitionist writings by American women such as Lydia Maria Child and Harriet Beecher Stowe, see Martin.

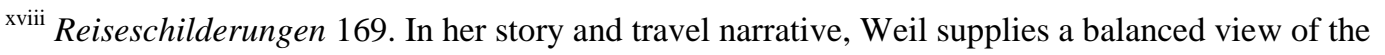
American press on both sides of the slavery issue, in contrast to other writers who denounced the press as controlled by proslavery sentiment (Hollyday 156).

xix This Harmonite colony was apparently not as actively abolitionist as Robert Dale Owen's community "New Harmony" or the Shaker communities, yet it maintained connections with active opponents of slavery and supported the cause of the North during the Civil War. See Lockwood 30, and Arndt 85-94. Berry also claims that the colony opposed slavery in Indiana (46). 
${ }^{\mathrm{xx}}$ It seems plausible that Weil set her story in an earlier era and location of the colony in order to avoid causing any offense to her friends at Economy. While there, she lodged in the home of the community's current leader, Becker; his sister Katharine was like a mother to her; and she was close to Rapp's granddaughter Gertrud (101-102). In the story, Weil omits the names of the communities, but supplies the locations, so that a reader must know something of the Rappist movement's history in order to locate the setting. A remark in the travelogue about the many newspaper articles and books available about Rapp — many of which judged him and the group unfavorably_indicates that her contemporaries could have readily identified the community as Harmonite (81).

${ }^{x x i}$ By the time Weil visited Economy, the youngest members were 40-50 years old, so that she could not observe the childhood of members first-hand. Instead she learned about Harmony days under Rapp's leadership from older members at Economy (Reiseschilderungen 82). She worked for the community teaching ten orphan children, but she relates little about their education, except to say that she had free reign to instruct them as she wished (85). Thus her depiction of the severity imposed on children of community members may convey as much about Weil's educational precepts as about the Harmonites' treatment of children.

${ }^{x x i i}$ In examining German women's travel writings, Scheitler concludes that these texts generally do not fundamentally question traditional gender norms (245). Anderson theorizes the position of the female travel writer, who is "compelled to operate in and through the mediations of the dominant culture." She "must accommodate herself to the rest of society, must live by the judgements of others in order that her Self may be both seen and heard” (20). 